Discourse and Communication for Sustainable Education, vol. 6, pp. 132-140, 2015

\title{
Holistic Approach as Viewed by the Basic School Teachers in Latvia
}

\author{
Jeḷena Badjanova and Dzintra Iliško \\ Daugavpils University, Latvia
}

\begin{abstract}
The article points to new competencies required from basic school teachers, reinforced by the reform processes in the educational system in Latvia, the quality assurance of educational process, and modernisation and critical re-evaluation of educational materials and standards. The authors view sustainability as an integral part of reform processes in the country.

The aim of the study is to evaluate the perspective of basic education teachers from the diverse regions of Latvia on the use of holistic approach for shaping the content of basic education. The authors have analysed basic school teachers' understanding of a holistic approach towards teaching and a learner. By means of a survey the authors have explored the features of teachers' perception of a holistic approach to their teaching. The authors conclude that sustainability cannot be left to the initiative of individual teachers but should be implemented as a whole-school policy.
\end{abstract}

Keywords: holistic approach, sustainable education, education, basic school teacher, the child as a whole

\section{Introduction}

Nowadays the aims of preschool, primary and secondary education curricula are related to social values - culture, lifelong education, and a personality development (Andersone, 2007). This target orientation spawns discussion about the need for conceptual changes in education, not least about innovation in the fields of pedagogy and didactics (Schreiner, 2005; Van Kannel-Ray, 2006). A number of internationally binding normative documents are passed, which bring the issue of educational reform high on the agenda.

Sustainable Development Strategy of Latvia until 2030 concedes that, in response to global developmental tendencies and challenges, long-term developmental priorities and solutions ought to be created with a view to ensuring effective and sustainable management of national cultural, natural, economic and social potential. This strategic document also highlights the need to replace the current teaching paradigm with "a creativity-oriented learning paradigm" (Sustainable development strategy of Latvia until 2030, p. 14). According to the strategy, a creative individual and a creative society, capable of evaluating and tapping into their creative potential, are "major developmental 
forces, only such society can think and act in a sustainable fashion" (Sustainable development strategy of Latvia until 2030, p. 14)

National standard of primary education curriculum and other normative documents (ISEC, 2004; VISC, 2013a, 2013b) emphasise the importance of appraising the depth of cultural values in a comprehensive general education that is oriented towards integration and sustainable development.

Regrettably, the dominant model of teacher-learner interaction in the formal educational environment is still the teacher positioned at the front of the classroom expecting learners to regurgitate 'correct' answers. Such arrangement is not conductive to the development of critical thinking and creativity among learners. Its inherently problematic nature is further exacerbated by inadequate qualification of the teaching staff as compared to the global standard, and persistent inequality in terms of access to quality education between rural and urban areas (Schreiner, 2005). In view of the above, teaching for sustainable development cannot be left to depend on the initiative of isolated teachers or limited to a few subjects in the curriculum. It should become a whole-school priority policy throughout the country.

Latvian system of education is shaped in a way that conforms to the general European framework and follows the provisions and aims of Bologna Declaration. UNESCO report on perspectives for education in the 21st century (UNESCO, 1998) points the following paths to be pursued: fine-tuning existing curricula to align with the aims of sustainable development and upgrading current system of basic education in ways which would let children take central stage as actors who will shape the social consciousness of the future.

Since the close of the 20th century, the terms 'sustainable development' and 'holistic approach' have been used in close association in scientific pedagogical literature and in normative documents that regulate the process of education in Latvia.

The above analysis leads to the aim of the study: to evaluate the perspective of basic education teachers from the regions of Latvia on the usage of holistic approach for shaping the content of basic education.

\section{Theoretical Underpinnings of Holistic Approach}

Sustainable development of society is conditionally dependent on a re-examination of core principles that underlie current social and cultural systems, not least the principles of a holistic approach, as well as on questioning such tenets as respect to individuality, unconditional following of an established code of ethics and implicit respect for the law. There is no general agreement on what holistic approach actually means. A wealth of different definitions and interpretations pervades contemporary scientific discourse (Salite, 2008) with the general line of argument being that holistic approach involves development of such knowledge, skills and values which should enable learners to become active, democratic and responsible citizens capable of making informed decisions. An environment shaped according to the holistic approach (Smuts, 1926) is construed as purposefully created conditions which meet each learner's educational needs, are underpinned by a positive mutual relationship, help learners succeed academically, motivate acquisition of new knowledge and development of new skills as well as nurture the learners both emotionally and physically in a socially integrated and constructive setting. 
The present study involves an evaluation of what meaning is attributed to the term 'holistic approach' in the writings of Latvian and foreign scholars and researchers (Salite, 1998; Wilber, 2006) and in international normative documents (UNESCO, 2005; 2011). The analysis revolves around such concepts as 'systemic', 'integrated', 'wholistic' and 'joint-wholistic' approach.

Holistic approach becomes integrated in spiritually oriented writings on psychotherapy in order to expand the relationship between psychotherapy and spirituality. Psychologists increasingly come to realise that spiritual and psychological problems are one and constitute a single unbroken spectrum (Litke, 2004). Many scholars discuss the approach of an integrated whole in personality development and use the term 'integral individuality' to analyse personality as a whole, labelling it a 'holistic personality' (Wilber, 2006). The content of holism as a concept is also defined as a dimension of an integral education: a totality of cognitive, economic, social and emotional aspects, and quantitative and qualitative values (Nakagawa, 2000; Nava, 2001; Forbes, 2003; Badjanova, 2013, 2014). Constructivist ideas on the cultural and educational aspects of society (Richardson, 1997; Taylor, 1998; Pipere, 2005) suggest that holistic education subsumes a person's individual experience, physical and spiritual abilities and image construction in a totality, in a system. Consequently, one can conclude that systemic approach can be viewed as a content aspect of holistic approach. Individual characteristics within a single subsystem of an integral individuality are closely and unequivocally bound with the holistic function of development sustaining these diverse ties. Many pedagogues and researchers consider personality as an organisation of structured levels, as an 'integral system'. An integral individuality is seen as manifesting itself as a system through the entire array of its activities which take multiple forms such as mental activity and selfdirection (Wilber, 2006; Badjanova, 2013, 2014).

In the following section holistic approach will be analysed in the context of formal basic education with reference to different theories and normative documents.

\section{Pedagogical Principles of Holistic Approach for Shaping the Content of Basic Education}

Legal documents such as Law on Vocational Education, Law on Education and other legal acts regulate national vocational education policy and the operation of vocational education system. Basic education prepares for secondary education or for professional activity; it involves mastering basic knowledge and skills as well as developing a values orientation for one's future life. Children begin their basic education when they turn seven years old. Acquisition of basic education is mandatory until the learner turns eighteen. Basic education programmes are implemented over a nine-year period. Mandatory basic education curriculum is determined by national basic education standard. Once they complete a basic education programme, learners receive a certificate on general basic education and a list of grades. Their evaluation in the subjects that require passing a centralised exam is confirmed by basic education certificate (ISEC, 2004).

The content of holistic approach suggests that teaching involves not only drilling learners to regurgitate 'dry' subject matter, but also proposing various techniques which they could use to apply what they have learnt. It helps to develop a versatile personality and enables learners to find real-life application to their knowledge. For instance, ecolo- 
gical problems can be addressed through economic solutions as well as viewed through the lens of religion; patriotism and cultural issues can be explored in music. When the teacher explains something to the learners in a creative fashion by using an out-of-thebox example, it bears favourably on the development of the learners' creativity. When the teacher bridges different disciplines, it supports learners' integral thinking. The latter subsumes both rational and magical thinking (Salite, 1998). Integral thinking cannot exist without creative perception of the world. The teacher should realise that creativity is a process which includes one's attitude to other people and can help find original solutions to everyday problems. Human body, mind and feelings are all involved in creativity, which makes a human individual develop as a whole, become a personality who is capable of developing and sustaining our world for the future. The content of integral learning is a set of knowledge, techniques and attitudes which enable learners to develop intellectually, emotionally and cognitively, and improve their work skills and habits. Integral learning in active participation ensures the child's all-round development, promotes the activity of both hemispheres of the brain, and involves both abstract and figurative thinking.

The teacher acts as a helpmate who can assist the child in comprehending, for instance, that the Earth's capacity to satisfy human needs is finite, so humans need to change not only for the sake of our common future, but also to retain our physical health (Salite, 1998), preserve our historical legacy and traditions, and enable the future generation to bring up their own progeny. Thus, holism is regarded as a personality's integrative and systematising function, as a phenomenon of integral individuality in the structure of personality's holistic conception (Miller, 1993). For many years, creators of curricula strive to attest that school does not teach subject matter but nourishes human growth and education: helps an individual who is already living better prepare for life in the future.

A lesson is a form of organising learning where the teacher works for a fixed span of time and with a fixed group of learners. During a lesson, the learner must acquire new knowledge; moreover, each lesson should be educational. The child cannot be developed in bits and parts. Everything is interrelated. The child develops as a uniform personality; it follows that during a lesson the teacher should use the complex approach to educating which subsumes a joint and dialectical addressing of the child's intellectual, physical, labour, moral and aesthetic education. All tasks of educating a personality should be realised in one joint process of personality formation with due consideration of the child's age peculiarities and individual characteristics. Consequently, the teacher accepts the child as he or she is (Miller, 1993) and respects the child's unique lived experience. Holistic approach which is essentially integral and oriented from teaching to learning is more effective than other approaches in that it only accepts one innovation an active, social, child-centred approach backed with new technologies (Bundsgaard \& Hansen, 2011). Holistic approach to personality education requires a differentiated integration of discrete subjects in the pedagogical process whose key concerns are the following: learners' creative activity during learning; learning to independently acquire new knowledge; application of knowledge in novel situations; formation of a unified worldview; clear awareness of one's place and role in the society. The above concerns are conditioned by objective social and economic processes in the society as well as the 21 st century transition to an information society (Bundsgaard \& Hansen, 2011). Holistic 
approach to pedagogy emerged as an opposition to the functional approach that regards the pedagogical processes independently from the changes which occur at a given time within the person. The essence of the functional approach is a perspective on the pedagogical process which disregards the whole as a specifically structured system where each element performs a certain function and moves in accordance with the movement of the whole. Organisation of the pedagogical process according to the holistic approach requires an orientation towards the features of a person viewed as a whole - a complex psychic system with specific structure, function and composition.

Thus, holistic approach to pedagogical systems targets development of a person. First and foremost, it focuses on systemic regularities within a whole and their mutual interrelatedness, and on studying and forming constant and changing, primary and secondary factors of this whole. It means that a human being should be viewed as a whole with inherent differences in terms of gender, age, nationality and culture and schooling. What matters in holistic pedagogy is not only the child's capacity for inquiry, but also his or her physical, organisational, economical and labour related abilities. Holistic education is not just a process, in which the child acquires theoretical knowledge, develops a notion of reality, goes through emotional experiences and accumulates specific values; essentially, it is a practical creation and transformation of new things and ideas (Miller, 1993; Huckle, 2003; Bundsgaard \& Hansen, 2011; Badjanova, 2013; Badjanova \& Iliško, 2014).

Principles of holistic approach suggest specific changes in pedagogical theory and practice as well as direct the development of the entire educational system towards sustainability. Provided the human being is viewed as an integral whole of body and mind, senses and emotions, the knowledge acquired by the learner should reflect a united holistic function - how to render the human life more complete, for education is not confined to one subject; rather, it is life itself in all its manifestations (Smuts, 1926; Miller, 1993).

The following section describes the research sample as well as outlines and interprets the findings.

\section{Research Participants}

The study involved 353 basic education teachers from general secondary schools in different regions of Latvia, including 47 music teachers. Survey respondents' mean age was 44 years, $25 \%$ of the participants were older than 50; mean work experience of the respondents was 20 years.

$58.8 \%$ (207) of the research participants had taken professional qualification courses in 2012 and $23.9 \%$ (84) had done so in 2013.

Teachers were asked to fill in a questionnaire on how they view the use of a holistic approach in their everyday situations and in the ideal situation. To analyse the factor structure of the questionnaire, exploratory factor analysis with identical criteria was performed for both the real and the ideal situation (Creswell, 2003). Factor analysis of different situations is performed according to a single template: by using the extraction method for principal component analysis with subsequent application of Varimax rotation with Kaiser Normalisation. 


\section{Holistic Approach in Latvian Regions as Perceived by Basic Education Teachers}

As the research results indicate, Kaeser-Meyer-Olkin measure of sampling adequacy (KMO) is 0.956 for the real situation and 0.947 for the ideal situation, which confirms the appropriateness of using factor analysis for analysing the questionnaire structure.

Factor analysis corroborated the triple factor structure of the phenomenon under study. The surfaced factors correspond to the communicative, social and cognitive components which characterise different strategies of teaching. The factor-like structure of the questionnaire is retained after factor analysis of discrete situations.

Reliability refers to a characteristic which reflects the coordination of the obtained measurement results. To assess the reliability (coordination) of questionnaire items, Cronbach's Alpha coefficient was used. The meanings of Cronbach's Alpha criterion range from 0.806 to 0.907 which suggests a relatively high coordination between discrete items in the questionnaire.

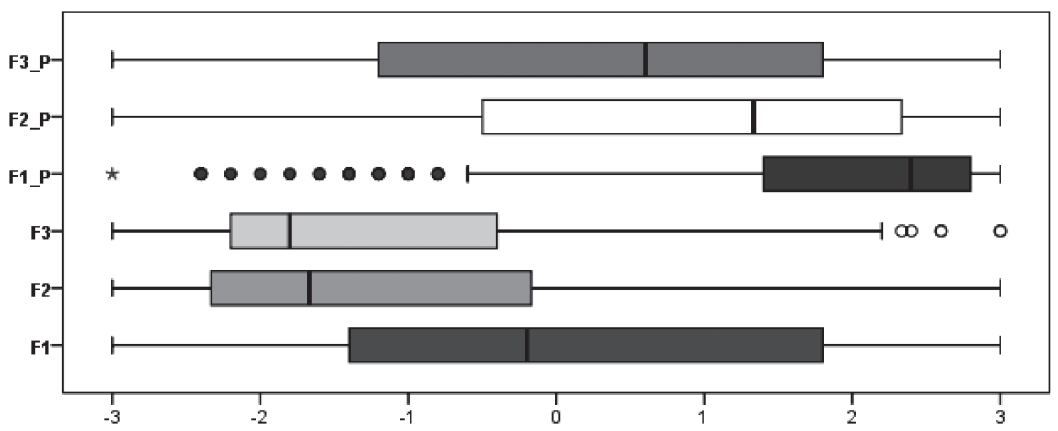

Figure 1. Boxplot diagrams of factors which characterise respondents' attitude to the strategy of teaching

Descriptive statistics analysis of the factors which characterise the respondents' attitude to strategies of teaching in real and ideal situations suggests that in real situations the research participants generally support instructionism whereas in ideal situations they appear to incline towards constructivism.

Assessment of identical factors in real and ideal situations is markedly different, but a significant correlation can be observed between the two. The most pronounced correlation is identified in the assessment of the communicative component of the strategy of teaching $(\mathrm{r}=0.382)$; the least pronounced correlation is evident in the cognitive component $(\mathrm{r}=0.182)$.

Two-stage cluster analysis in the space of the surfaced factors yielded four clusters of the same type. Qualitatively, these clusters can be described as follows.

The first cluster (K---) contains only $12.5 \%$ (44) of the respondents; they choose instructionism as the strategy of teaching in both real and ideal situations. Respondents from the second cluster (K+--) constitute $31.2 \%(110)$; they side with instructionism in the assessment of the social and the cognitive components and incline towards constructivism in the instance of the communicative component. The third cluster $(\mathrm{K}+++)$ contains $20.5 \%(72)$ of the respondents who support constructivism. The fourth cluster $(\mathrm{K}-+)$ is 
the densest of all, containing $35.8 \%$ (128) of all the respondents. They support instructionism in real situations and yet would side with constructivism in ideal circumstances (Badjanova, 2014).
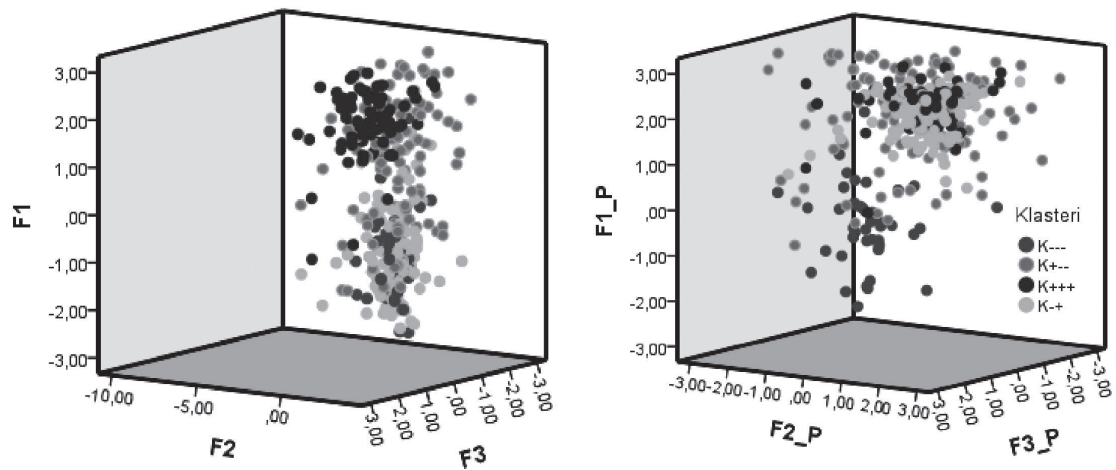

Figure 2. Positions of the respondents within the surfaced clusters in the space of the factors which characterise the strategy of teaching in the real and in the ideal situation

This study suggests that the principles of holistic approach can be successfully introduced in basic schools where the objectivist paradigm still continues to exert its influence on the teaching and learning process.

\section{Conclusion}

Shifting of educational paradigms leads to significant changes in the system of education in general (in terms of form and content, philosophy and manifestation, attitude and educational policy). These changes are also related to transformations in the socioeconomic structure of the country. Although a shift in educational paradigms is directly observable in pedagogical practice, it is underpinned by changes in teachers' thinking.

Holistic approach to education can significantly affect the quality of the teaching and learning process in basic school. To design a conceptual framework of a teaching and learning process rooted in the holistic approach to education, it is vital to evaluate not only the structure of teaching and learning, but also the procedural aspects such as learner's interaction with the teacher and the content of learning. It means evaluating how teachers construct the process in which learners acquire the content to be learnt.

Appropriate shaping of this process can ensure qualitative changes in learners' development and facilitate their growth and personality development. Key feature of this process should be learning to manage change. It means that teachers should encourage learners to be active participants in situations of social change rather than to prepare them to passively adapt to the social environment. 


\section{References}

Andersone, R. (2007). Mācību programmu izveides pedagoǵiskie principi. [Pedagogical principles of curriculum design]. Pedagogiija un skolotāju izglītība. (7-13 lpp.) Rìga: LU Akadēmiskais apgāds.

Badjanova, J. (2013). Primary school teachers' views on a holistic approach to facilitating the acquisition of musical cultural values. Journal of Teacher Education for Sustainability, 15 (2), 78-90.

Badjanova, J. (2014). Holistic approach to facilitating the acquisition of musical cultural values: primary education teachers'views. Saarbrücken: LAP LAMBERT Academic Publishing.

Badjanova, J., \& Iliško, Dz. (2014). Holistic philosophy based teaching approaches in Latvian primary schools: Primary education teachers' view. In V. Dišlere (Ed.), Proceeding of the international scientific conference "Rural Environment. Education. Personality.” (pp. 22-28). Jelgava: LLU.

Bundsgaard, J. S., \& Hansen, T. I. (2011). Evaluation of learning materials: A holistic framework. Journal of Learning Design, 4 (4), 31-44.

Creswell, J. (2003). Research design: Qualitative, quantitative, and mixed approaches. Thousand Oaks, CA: Sage.

Forbes, S. H. (2003). Holistic education: An analysis of its ideas and nature. Brandon, VT: Foundation for Education Renewal.

Huckle, J. (2003). Education for sustainable development: a briefing paper for the TTA. London: Teacher Training Agency.

ISEC (2004). Valsts mācību priekšmetu pamatizglìtības standarts. [National basic education standard of school subjects]. Rìga: IZM ISEC. Retrieved from http://www.isec. gov.lv/pedagogiem/standarti/standarti 1b.shtml

Lang, J. (2005). Education for sustainability. EQ Australia. Melbourne VIC: Curriculum Corporation.

Litke, B. (2004). The grammar of sustainability. In Proceedings of the EMSU 2004 sustainable development education: Holistic and integrative educational and management approaches for ensuring sustainable societies (pp. 1-10). Mexico: Monterrey.

Miller, J. P. (1993). The holistic teacher. Toronto: Canadian Cataloguing in Publication Data.

Nakagawa, Y. (2000). Education for awakening: An eastern approach to holistic education. Brandon, VT: Foundation for Education Renewal.

Nava, R. G. (2001). Holistic education: Pedagogy of universal love. Brandon, VT: Holistic Education Press.

Pipere, A. (2005). Primary and secondary teachers: Beliefs and performance related self - perceptions about engaged learning. Baltic Journal of Psychology, 6, 32-44.

Richardson, V. (1997). Constructivist teaching and teacher education: Theory and practice. In V. Richardson (Ed.), Constructivist teacher education: Building a world of new understanding (pp. 3-14). Bristol, PA: Falmer Press.

Salìte, I. (1998). Holisms sākumskolas izglìtībā. Sākums. [Holism in primary education. Beginnings]. Journal Skolotājs [Teacher] , 8, 28-29.

Salite, I. (2008). Educational action research for sustainability: constructing a vision for the future in teacher education. In A. Pipere (Ed.). Journal of Teacher Education for Sustainability, 10, 5-16. 
Schreiner, P. (2005). Contributions to holistic education from different theories. In P. Schreiner, E. Banev, \& S. Oxley (Eds.), Holistic education resource book: Learning and teaching in an ecumenical context (pp. 35-48). New York, München, Berlin: Waxmann Münster Verlag GmbH.

Smutss, J. C. (1926). Holism and evolution. New York: The MacMillan Company.

Taylor, P. (1998). Constructivism: Value added. In B. Fraser, \& K. Tobin (Eds.), The International handbook of science education (pp. 1111-1123). Dordrecht, The Netherlands: Kluwer Academic.

(UNESCO). United Nations Educational, Scientific and Cultural Organisation (1998). Izglìtība 21. gadsimtam. [Education for the 21st century]. Rīga: Vārti.

(UNESCO). United Nations Educational, Scientific and Cultural Organisation (2005). Guidelines for inclusion: Ensuring access to education for all. Paris: UNESCO.

United Nations Economic Commission for Europe. (2011). Learning for the future: Competences in education for sustainable development. Geneva: United Nations Economic Commission for Europe.

(VISC) Valsts izglitības satura centrs [National Centre of Educational Content] (2013a). Noteikumi par valsts pamatizglìtības standartu, pamatizglītības mācību priekšmetu standartiem un pamatizglitības programmu paraugiem. Retrieved from http://likumi. lv/doc.php?id=259125

(VISC) Valsts izglitīibas satura centrs [National Centre of Educational Content] (2013b). Noteikumi par valsts standartu pamatizglìtība un pamatizglìtības mācību priekšmetu standartiem. Retrieved from http://likumi.lv/doc.php?id=150407\%20

Van Kannel-Ray, N. (2006). Guiding principles and emerging practices for environmentally sustainable education. Curriculum and Teaching Dialogues, 8 (1/2), 113-123.

Wilber, K. (2006). Integral spirituality. A startling new role for religion in the modem and postmodern world. Boston: Shambhala Publications.

Correspondence concerning this paper should be addressed to Jeḷena Badjanova, Daugavpils University, Latvia. Email: helenija@inbox.lv 